\title{
Epitestosterone in Human Blood and Prostatic Tissue ${ }^{1}$ )
}

\author{
Luboslav Stárka ${ }^{1}$, Richard Hampl ${ }^{1}$, Martin Hill ${ }^{1}$, Oldřich Lapčik ${ }^{1}$, Radovan Bilek ${ }^{1}$ and Radko Petřik ${ }^{2}$ \\ 1 Institute of Endocrinology, Praha, The Czech Republic \\ 2 Urological Clinic, 1st Medical Faculty, Charles University, Praha, The Czech Republic
}

Summary: Epitestosterone, a $\mathrm{C}_{19}$-steroid with anti-androgenic activity, was determined in the plasma of 234 boys and men from the ages of 6-86 years, and in the prostate tissue of 15 men 55-82 years of age. It was documented that, while in adulthood the concentration of epitestosterone is about ten times lower than the concentration of testosterone, in the pre-pubertal period the level of epitestosterone is similar or even higher than that of testosterone. In the hyperplastic prostate tissue the content of epitestosterone is comparable to that of androstenedione, it is about twice as high as the content of testosterone and approximately half that of the content of dihydrotestosterone. At least in the case of pre-pubertal boys and in the prostatic tissue it is therefore possible to include epitestosterone into consideration as a regulatory factor for the androgen-dependent events.

\section{Introduction}

Epitestosterone, a $17 \alpha$-epimer of testosterone, was discovered as a mammalian endogenous steroid by Clark \& Kochakian in 1947 (1), and for 40 years it was considered as a biologically totally inactive compound (2). Certain attention was paid to it as an internal standard in steroid analysis used for the control of testosterone abuse by athletes, and the methodology, based on determining the ratio of testosterone to epitestosterone (3) in the urine, was recognized by the International Olympic Committee in 1987 as the criterion for proving the abuse of testosterone in sports.

In 1987 a short report appeared in dermatological literature on the effect of epitestosterone on the side organ of a golden hamster, in which this steroid inhibited the effect of testosterone on the skin adnexa. Epitestosterone was designated as an anti-androgen, even though the mechanism of this effect was not studied (4).

In our institute, and also in some other laboratories, some of the physiological effects of epitestosterone were therefore studied to elucidate the mechanism of its effect, as is summarized is table 1 .

These findings led us to seek the answer to the question as to whether epitestosterone is present in the circulation and tissues of humans in such a concentration to allow its anti-androgenic effects to play some role in hormonal homeostasis. While sufficient facts have been assembled in the literature on the urinary excretion of epitestosterone $(5,25,26)$, data on its concentration in human blood

1) The study was supported by grant No. 1432-3 of the Internal Grant Agenture of the Ministry of Health of the Czech Republic. were rare (5) and so far there are none at all on its tissue concentration. Therefore we attempted

1) to ascertain the concentrations of epitestosterone in the blood of boys and men of various age groups, and

2) to find out to what extent the concentration of epitestosterone in the tissue of the hyperplastic prostate can compete with the concentrations of androgens in this secondary sexual gland.

Tab. 1 Some reported effects of epitestosterone

\begin{tabular}{|c|c|c|}
\hline In vivo and in vitro effects & Animal & Reference \\
\hline Inhibition of sebaceous glands & hamster & (4) \\
\hline $\begin{array}{l}\text { Inhibition of hair follicle } \\
\text { development }\end{array}$ & hamster & (4) \\
\hline $\begin{array}{l}\text { Reduction in the weight of } \\
\text { androgen-dependent organs }\end{array}$ & rat, mouse & (6) \\
\hline $\begin{array}{l}\text { Competitive binding on the } \\
\text { androgen receptors }\end{array}$ & rat & (6) \\
\hline Inhibition of steroid $5 \alpha$-reductase & rat & $(6,19)$ \\
\hline $\begin{array}{l}\text { Inhibition of } 17 \alpha \text {-hydroxylase and } \\
17,20 \text {-lyase }\end{array}$ & rat, human & $(7,8)$ \\
\hline Antirenotropic effect & mouse & $(20)$ \\
\hline $\begin{array}{l}\text { Inhibition of } 11 \beta \text {-hydroxysteroid } \\
\text { dehydrogenase }\end{array}$ & rat & (9) \\
\hline Inhibition of spermatogenesis & rat & (11) \\
\hline $\begin{array}{l}\text { Modulation of secretion and } \\
\text { production of lutropin and } \\
\text { follitropin }\end{array}$ & rat & $(10,21)$ \\
\hline Inhibition of bone mineralization & mouse & $(22)$ \\
\hline $\begin{array}{l}\text { Effect on experimental carcinoma } \\
\text { of the prostate }\end{array}$ & human, rat & (23) \\
\hline $\begin{array}{l}\text { Non-genomic effect on relaxation } \\
\text { of the uterine muscle }\end{array}$ & rat & $(24)$ \\
\hline
\end{tabular}




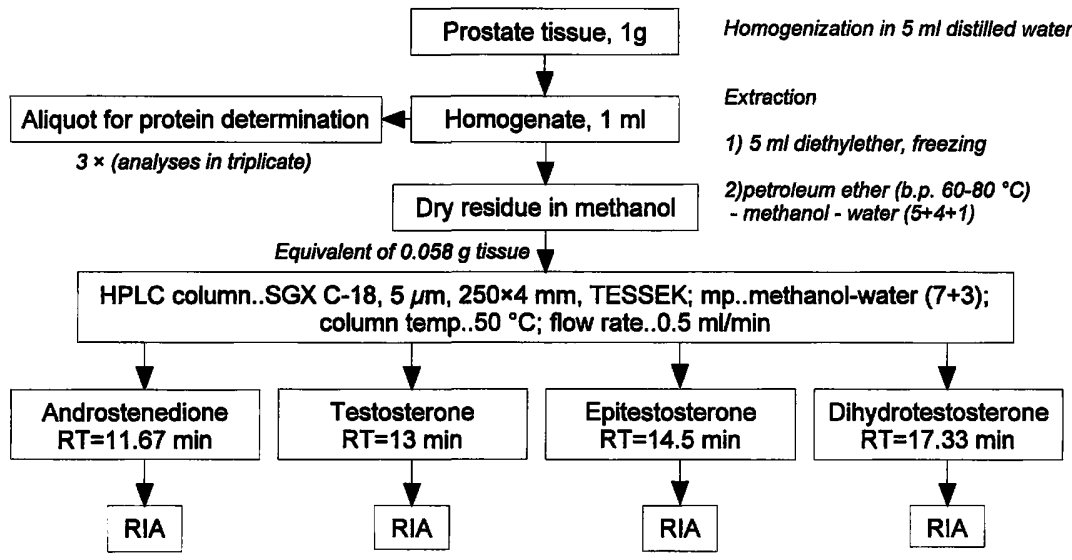

Scheme 1 Flow-chart of the method for the determination of epitestosterone and other $\mathrm{C}_{19}$-steroids by HPLC and radioimmunoassay.

b. p. = boiling point; $\mathrm{RT}=$ retention time

\section{Materials and Methods}

Healthy subjects, patients and blood and tissue sampling

In order to determine the normal concentration of epitestosterone, blood was taken from 156 healthy individuals in the age group 6-65 years, who had been invited by random selection for a survey of iodine deficiency in the district of Ústí, as a part of another research project (12).

We completed the group of elderly men with 78 otherwise healthy men of up to 86 years of age, who had been invited at random into the general practitioner consulting room for prostate-specific antigen screening in another study. The blood was withdrawn from the cubital vein between $8-10$ in the morning into heparin coated vials. Not more than $2 \mathrm{~h}$ later plasma was separated and stored in a freezer at $-20^{\circ} \mathrm{C}$ until processed in the laboratory.

The tissue samples of the hyperplastic prostates were obtained from 15 patients who had been operated on in the period October-December 1993 for adenoma of the prostate with transabdominal suprapubic entry at the Urological Clinic of the 1st Medical Faculty of the Charles University in Prague. The patients were between the ages of 55-82 years, the average weight of the dissected gland was $60.5 \mathrm{~g}$. The criteria for exclusion from the group were a former or contemporary medical therapy of hyperplasia of the prostate, hormonal treatment of any type for three months before the operation and defects of the liver metabolism. The tissue removed surgically was examined histologically by a pathologist and stored in a freezer at $-20^{\circ} \mathrm{C}$. For details see 1.c. (13).

\section{Determination of steroids}

The tissue steroids were extracted and cleaned according to Scheme 1 by liquid chromatography under the conditions given in detail elsewhere (13), the plasmatic steroids were determined without chromatographic purification, the plasma epitestosterone was determined by the extraction technique according to Bilek (5). The epitestosterone was determined by the original radioimmunological method (5), testosterone, androstenedione and dihydrotestosterone were determined by conventional radioimmunoassay $(14-16)$. For the method of steroid determination in prostatic tissue the recovery was checked by spiking with $500 \mathrm{pg}$ of each steroid per $\mathrm{g}$ of tissue. The recovery was $88.2 \%, 89.1 \%, 93.0 \%$, and $115 \%$, respectively for androstenedione, testosterone, epitestosterone and dihydrotestosterone.

\section{Statistical analysis}

The values are given as arithmetical average \pm SEM and median \pm standard deviation of median. The t-test for different group vari- ances was used for inter-group comparison. Partly the linearized regression was carried out by the method of weighted least squares, partly the stepwise polynomial regression for constants of polynomials lying on the level of probability $\mathrm{p}<0.05$ was performed. The statistical significance of the correlation coefficients was determined by the $\mathrm{F}$ test.

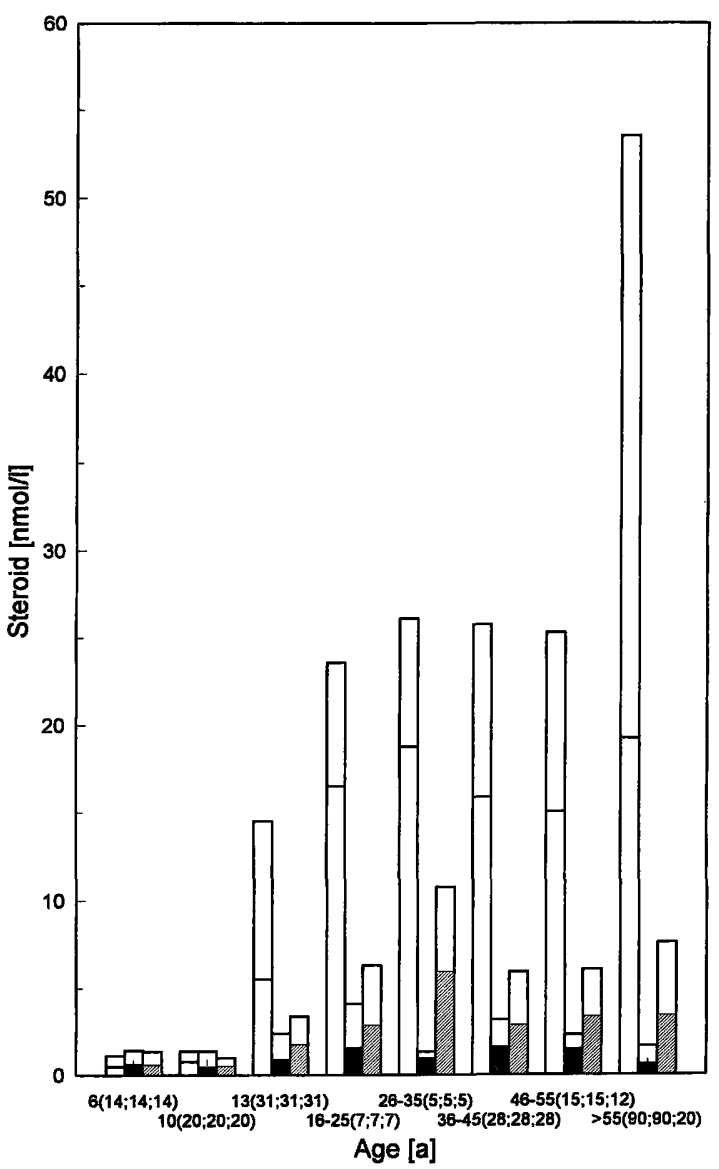

Fig. 1 Plasma concentration of testosterone, epitestosterone, and dihydrotestosterone in boys and men depending on age (in parentheses: $n$ ).

grey bar: testosterone; black bar: epitestosterone; light grey bar: dihydrotestosterone mean +2 S. D. 

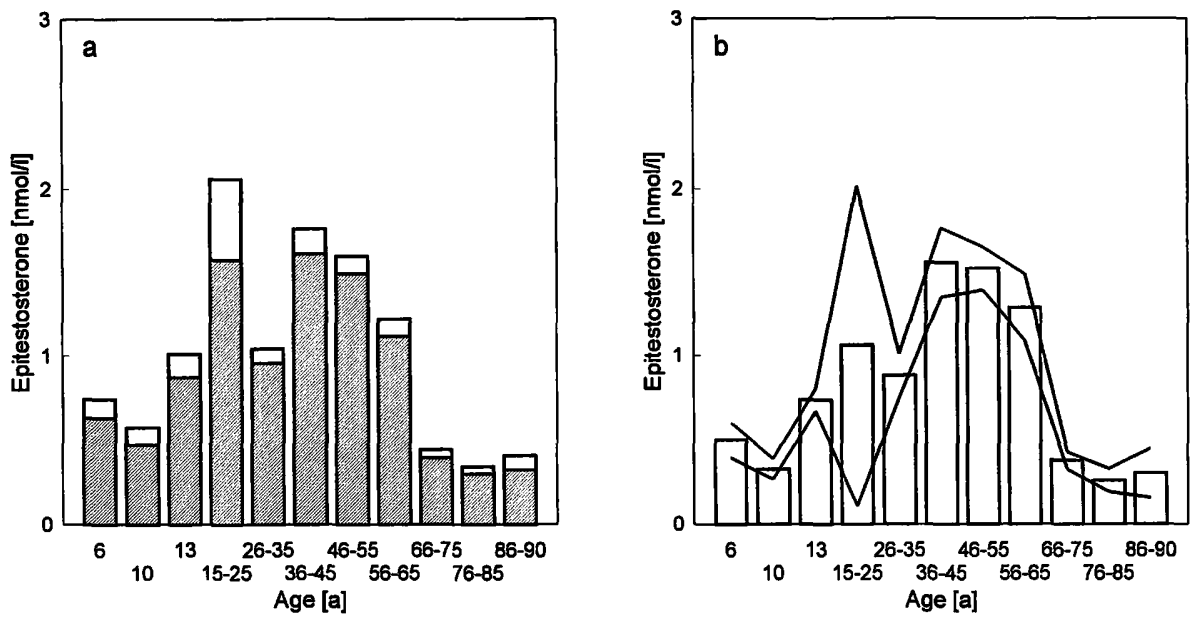

Fig. 2 Age-dependence of plasma concentration of epitestosterone.

a) average values + S.E. M., b) median + S. E. of median.

\section{Results}

The normal concentration of epitestosterone in the blood of males and its dependence on age

The average concentration of epitestosterone, dihydrotestosterone and testosterone in the plasma of boys and men in various age groups from 6 to 65 years is given in figure 1 . In the case of all the observed $\mathrm{C}_{19^{-}}$ steroids there is a remarkable rise in the level in the course of puberty, and the highest average concentration is in the age group of 26-35 years, with the exception of epitestosterone, which maintains a practically constant level in all age groups after attaining adulthood. The lower concentration in the age group of men of 2635 years may be due to the limited size of this age category. The increasing trend in puberty is most striking in testosterone, and least marked in epitestosterone. The course of age dependence of the average levels of epitestosterone is given in figure $2 a$, the median in figure $2 b$. The significance of the differences between the various age groups for epitestosterone is shown in table 2. The course of the ratios of concentration of epitestosterone to the concentration of testosterone depending on age is given in figure 3.
The level of epitestosterone correlates positively with testosterone and with dihydrotestosterone $(r=0.586$, $\mathrm{p}<0.001$, resp. $\mathrm{r}=0.417, \mathrm{p}<0.001$ ) and the ratio epitestosterone : testosterone correlates with age according to the equation $y=0.0875+36.8 / x^{2}(r=0.759$, $\mathrm{p}<0.01$ ). In childhood, at the age of 6 years the concentration of epitestosterone is on the average higher than the concentration of testosterone, later ratio changes exponentially in favour of testosterone and after puberty it remains practically constant with approximately ten times the amount of testosterone as compared with epitestosterone.

\section{Concentration of epitestosterone in the tissue of hyperplastic prostate}

The concentrations of epitestosterone, testosterone, dihydrotestosterone and androstenedione in the tissue samples taken from 15 men between the ages of 55-82 years are given in table 3 . The average tissue concentration of epitestosterone is roughly twice as high as that of testosterone, half that of dihydrotestosterone and close to that of androstenedione.

Tab. 2 The significance of the difference in the plasma levels of epitestosterone between various age groups of men.

\begin{tabular}{lllllllll}
\hline Age group (years) & $0-6$ & $7-10$ & $11-13$ & $14-25$ & $26-35$ & $36-45$ & $46-55$ & $56-65$ \\
\hline $0-6$ & - & NS & NS & NS & + & ++ & ++ & ++ \\
$7-10$ & & - & + & NS & ++ & ++ & ++ & ++ \\
$11-13$ & & & - & NS & NS & ++ & ++ & ++ \\
$14-25$ & & & & - & NS & NS & NS & NS \\
$26-35$ & & & & & - & ++ & NS & NS \\
$36-45$ & & & & & & - & NS \\
$46-55$ & & & & & & & & - \\
$56-65$ & & & & & & & & \\
\hline
\end{tabular}

The significance of differences between groups was tested with the 


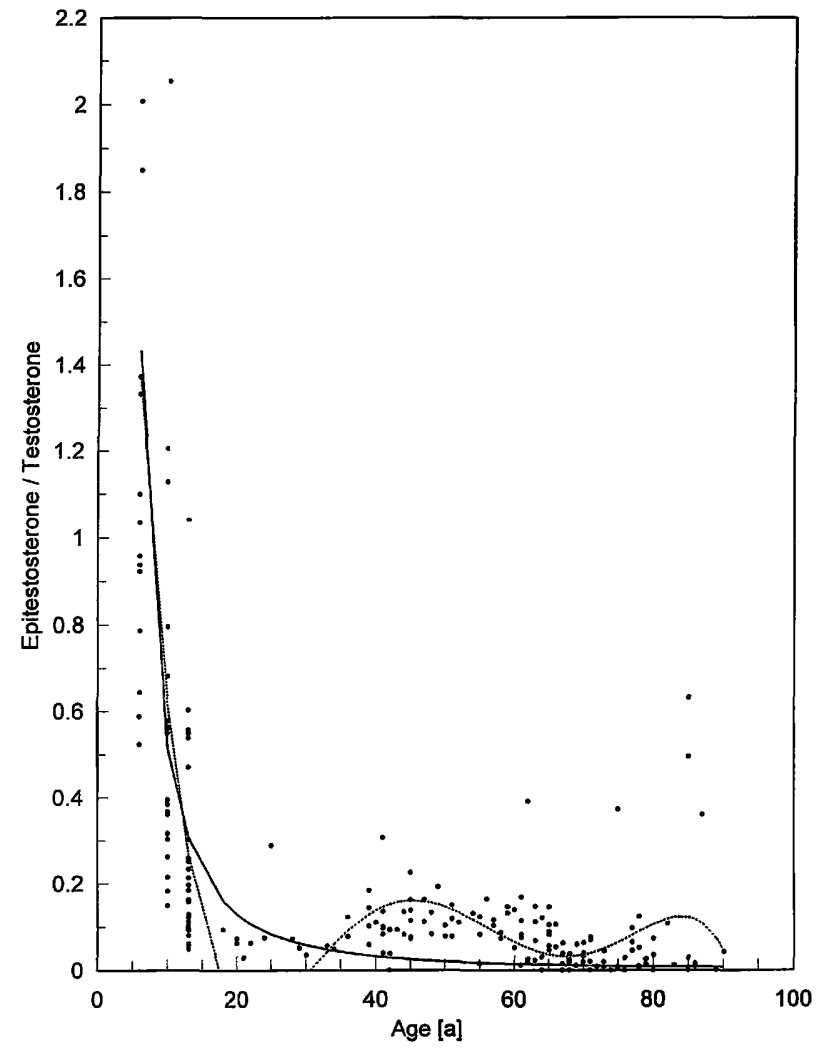

Fig. 3 Dependence of the ratio of concentrations of epitestosterone: testosterone in the plasma of boys and men on age. full line: $\mathrm{y}=0.0875+36.8 / \mathrm{x}^{2}(\mathrm{r}=0.759, \mathrm{p}<0.01)$ dotted line: $\mathrm{y}=\mathrm{a}+\mathrm{bx}+\ldots \mathrm{fx}^{5}(\mathrm{r}=0.659 ; \mathrm{p}<0.01)$

The tissue concentration of epitestosterone correlates positively with age $(\mathrm{r}=0.556, \mathrm{p}<0.05)$, and even closer is the correlation of the ratio epitestosterone : testosterone with age $(r=0.767, \mathrm{p}<0.01)$.

The tissue concentration of epitestosterone correlates linearly with the concentration of androstenedione $(\mathrm{r}=$ $0.634, \mathrm{p}<0.05)$ and dihydrotestosterone $(\mathrm{r}=0.671, \mathrm{p}<$ 0.05 ), but not with the concentration of testosterone.

\section{Comparison of the concentrations of} epitestosterone and androgenic steroids in the blood and in the prostate tissue

The ratio of epitestosterone : (testosterone + dihydrotestosterone) in the plasma was 0.08 , whereas in the tissue of the hyperplastic prostate it amounted to an average value of 0.386 .

\section{Discussion}

Epitestosterone in humans is not a metabolite of testosterone and its excretion is not dependent on the level of testosterone. Its biosynthesis takes place for the most part in the testicles, where its precursor is pregnenolone (17). The production rate of epitestosterone is only $3 \%$ of the production rate of testosterone, but its excretion is about $1 / 3$ of the excretion of testosterone (18). As mentioned in the introduction, various experimental evidence has been brought so far concerning the anti-androgenic effect of epitestosterone in animals.

In humans we have documented the endogenous levels of epitestosterone in males during the life span, which has not been systematically studied. It has been found that in the course of sexual development there appears a marked change in the ratio of epitestosterone to testosterone. In pre-puberty epitestosterone predominates over testosterone, while in adult men approximately a ten times greater amount of testosterone occurs in the blood.

In men's hyperplastic prostate tissue epitestosterone is present in a concentration higher than testosterone, and approximates about half of that of dihydrotestosterone. In prostatic tissue in comparison with the blood the content of epitestosterone is relatively increased in contrast to androgens present. This is probably the result of different pharmacokinetics and pharmacodynamics of epitestosterone.

Provided that the binding to the receptor is comparable (for epitestosterone $\mathrm{K}_{1}=29.8 \mathrm{nmol} / \mathrm{l}$, for dihydrotestosterone $\mathrm{K}_{1}=14.9 \mathrm{nmol} / \mathrm{l}(6)$ ), at least the same, or better, ten times higher concentrations of antagonists than those of agonists are necessary for evident antihormonal effects. Epitestosterone circulating in the blood in the pre-pubertal period approaches fulfillment of these conditions, and so does the tissue epitestosterone in the prostate of adult men. So it can be assumed that this steroid, long considered fully inactive, might act as an anti-androgen and as an inhibitor of $5 \alpha$ reductase in the regulation of androgenization of the male organism during sexual maturation and in the regulation of androgen-dependent tissue processes, at least as their modulator.

Tab. 3 Concentration of epitestosterone and androgens in the tissue of hyperplastic prostates

\begin{tabular}{lllll}
\hline & $\begin{array}{l}\text { Androstenedione } \\
\text { (fmol/mg protein) } \\
\mathrm{n}=14\end{array}$ & $\begin{array}{l}\text { Testosterone } \\
(\mathrm{fmol} / \mathrm{mg} \text { protein) } \\
\mathrm{n}=14\end{array}$ & $\begin{array}{l}\text { Epitestosterone } \\
\text { (fmol/mg protein) } \\
\mathrm{n}=15\end{array}$ & $\begin{array}{l}\text { Dihydrotestosterone } \\
\text { (fmol/mg protein) } \\
\mathrm{n}=15\end{array}$ \\
\hline Average & 71.6 & 28.2 & 58.4 & 122 \\
SEM & 8.1 & 3.6 & 10.4 & 7.9 \\
Range & $22.5-132$ & $12.1-61.7$ & $14.0-144$ & $53.4-165$ \\
Median & 74.6 & 26.6 & 47.7 & 133 \\
\hline
\end{tabular}




\section{Conclusion}

Epitestosterone, an endogenous steroid, long considered biologically fully inactive, has a proven antiandrogenic effect and inhibits the biosynthesis of androgens. It has been documented that its concentration in the plasma of boys before puberty and the contents in the tissue of the hyperplastic prostate in men

\section{References}

1. Clark LC, Kochakian CD. The in vitro metabolism of testosterone to $\Delta^{4}$-androstenedione- 3,17 , cis-testosterone and other steroids by rabbit liver slices. J Biol Chem 1947; 170:23-33.

2. Dorfman RI, Shipley RA. Androgens. New York: John Willey, 1986:124.

3. Donike MJ, Zimmermann K, Barwald K, Schanzer W, Christ V, Klostremann K, et al. Routinebestimmung von Anabolika im Harn. Dtsch Z Sportmedizin 1984; 35:14-24.

4. Nuck BA, Lucky AW. Epitestosterone: a potential new antiandrogen. J Invest Dermatol 1987; 89:209-11.

5. Bilek R, Hampl R, Putz Z, Stárka L. Radioimmunoassay of epitestosterone, methodology, thermodynamic aspects and applications. J Steroid Biochem 1987; 28:723-9.

6. Stárka L, Bičiková M, Hampl R. Epitestosterone - an endogenous antiandrogen? J Steroid Biochem 1989; 33:1019-21.

7. Bičíková M, Hampl R, Stárka L. Epitestosterone - a potent competitive inhibitor of steroid side chain cleavage in the testis. J Steroid Biochem 1992; 43:721-4.

8. Bičíková M, Hampl R, Hill M, Stárka L. Inhibition of steroid 17a-hydroxylase and C17,20-lyase in the human testis by epitestosterone. J Steroid Biochem Mol Biol 1993; 46:515-8.

9. Bičiková M, Hampl R, Stárka L. The factors influencing $11 \beta-$ hydroxysteroid dehydrogenase in rat testes. In: Solberg $R$, Hansson V, editors. Proceedings of the 9th European Testis Workshop on Molecular and Cellular Endocrinology; 1996 Apr 14-19, Geilo, Norway. Oslo: E. Schering Res. Found. Workshop, 1996: A1.

10. Lapčík O, Perheentupa A, Bičíková M, Hampl R, Stárka L. The effect of epitestosterone on gonadotropin synthesis and secretion. J Endocrinol 1994; 143:353-8.

11. Behre HM, Hampl R, Lapčík O, Hill M, Stárka L. The effect of epitestosterone on spermatogenesis in rats. Endocr Regul 1995; 29:195-9.

12. Lapčík O, Hampl R, Hill M, Stárka L. Plasma levels of epitestosterone in male from childhood to senescence. J Steroid Biochem Mol Biol 1995; 55:405-8.

13. Hill M, Hampl R, Petrík R, Stárka L. Concentration of the endogenous antiandrogen epitestosterone and androgenic $\mathrm{C} 19$ steroids in hyperplastic prostatic tissue. Prostate 1996; 28:347-51.

14. Hampl R, Dvořák $P$, Lukešová Š, Kozák I, Chrpová M, Stárka $\mathrm{L}$. The use of iodinated steroid as radioligand for testosterone radioimmunoassay. J Steroid Biochem 1978; 9:771-3.

15. Puri V, Puri CP, Kumar TCA. Serum levels of dihydrotestosterone in male rhesus monkey estimated by a non-chromatographic radioimmunoassay method. J Steroid Biochem 1981; 14:877-81. reaches values that can be assumed to counteract the effect of the androgens present.

\section{Acknowledgements}

This study was supported by a grant of the Internal Grant Agency of the Ministry of Health of the Czech Republic No. 1432-3.

16. Putz Z, Hampl R, Vaňuga A, Velemínský, Stárka L. A selective radioimmunoassay of androstenedione in plasma and saliva. J Clin Chem Clin Biochem 1982; 20:761-4.

17. Weusten JJAM, Legemaat G, Vander Wouvw MPME, Smals AGH, Kloppenborg PWC, Benraad TJ. The mechanism of the synthesis of 16-androstenes in human testicular homogenates. J Steroid Biochem 1989; 32:689-94.

18. Wilson H, Lipsett MB. Metabolism of epitestosterone in man. J Clin Endrocrinol Metab 1966; 26:902-14.

19. Monsalve A, Blaquier JA. Partial characterization of epididymal 5-reductase in the rat. Steroids 1977; 30:41-51.

20. Stárka L, Broulık P, Hampl R, Nedvídková J, Hill M. Antirenotropic action of antiandrogens cyproterone acetate, casodex, flutamide and epitestosterone. Endocr Regul 1996; 30:93-7.

21. Bičíková $M$, Kančeva $R$, Lapčík $O$, Hill M, Stárka $L$. The effect of epitestosterone on the plasma levels of LH and FSH in ovariectomized immature rats. J Steroid Biochem Mol Biol 1993; 45:321-4.

22. Broulik PD, Stárka L. The effect of the antiandrogens casodex and epitestosterone on bone composition in mice. Bone 1997. In press.

23. Maucher A, von Angerer E, Hampl R, Stárka L. Activity of epitestosterone in hormone dependent prostate tumour model. Endocr Regul 1994; 28:23-9.

24. Perusquia M, Hernández R, Kubli-Grafias C. Epitestosterone induces testosterone-like uterine relaxation. Proceedings of the 10th International Congress of Endocrinology; $1996 \mathrm{Jun}, \mathrm{Ab}-$ stract no. P2-578; San Francisco.

25. Dehenin L, Matsumoto AM. Long-term administration of testosterone enanthate to normal men: alterations of the urinary profile of androgen metabolites potentially useful for detection of testosterone misuse in sport. J Steroid Biochem Mol Biol 1993; 44:179-89.

26. Kuoppasalmi K, Karajalainen U. Doping analysis in Helsinki 1983. In: Tehunen R, editor. Clin Chem Res Found Publ Ser, Helsinki: Painoztalo Miktor, 1994; 1:32-5.

\section{Received January 17/April 11, 1997}

Corresponding author: Professor Dr. Luboslav Stárka, Endokrinologický ústav, Národní 8, CZ-11694 Praha 1, Czech Republic 
